University of Nebraska - Lincoln

DigitalCommons@University of Nebraska - Lincoln

Finance Department Faculty Publications

Finance Department

2005

\title{
Additions to corporate boards: The effect of gender
}

Kathleen A. Farrell

University of Nebraska Lincoln, kfarrell2@unl.edu

Philip L. Hersch

Wichita State University, philip.hersch@wichita.edu

Follow this and additional works at: https://digitalcommons.unl.edu/financefacpub

Part of the Finance and Financial Management Commons

Farrell, Kathleen A. and Hersch, Philip L., "Additions to corporate boards: The effect of gender" (2005).

Finance Department Faculty Publications. 18.

https://digitalcommons.unl.edu/financefacpub/18

This Article is brought to you for free and open access by the Finance Department at DigitalCommons@University of Nebraska - Lincoln. It has been accepted for inclusion in Finance Department Faculty Publications by an authorized administrator of DigitalCommons@University of Nebraska - Lincoln. 
Published in Journal of Corporate Finance 11 (2005), pp. 85-106; doi: 10.1016/j.jcorpfin.2003.12.001 Copyright (C) 2005 Elsevier B.V.

Used by permission. http://www.elsevier.com/locate/econbase

Submitted November 1, 2003; accepted December 1, 2003; published online April 20, 2004.

\title{
Additions to corporate boards: The effect of gender
}

\author{
Kathleen A. Farrell \\ Department of Finance, University of Nebraska-Lincoln, Lincoln, NE 68588-0490 \\ (Corresponding author - tel 402 472-3005, fax 402 472-5140, email kfarrell2@unl.edu ) \\ Philip L. Hersch \\ Department of Economics, Wichita State University
}

\begin{abstract}
During the decade of the 1990s the number of women serving on corporate boards increased substantially. Over this decade, we show that the likelihood of a firm adding a woman to its board in a given year is negatively affected by the number of woman already on the board. The probability of adding a woman is materially increased when a female director departs the board. Adding a director, therefore, is clearly not gender neutral. Although we find that women tend to serve on better performing firms, we also document insignificant abnormal returns on the announcement of a woman added to the board. Rather than the demand for women directors being performance based, our results suggest corporations responding to either internal or external calls for diversity.
\end{abstract}

Keywords: board of directors, board composition, diversity, gender

\section{Introduction}

Diversity in the workforce has been an issue receiving a tremendous amount of attention both in academia and in the popular press. Much of the initial focus and research relates to impediments to promotion of women at lower and middle management levels, often referred to as a glass ceiling effect. More recently, research has begun to focus on female representation in top management positions and corporate boardrooms (e.g., Kesner, 1988; Bilimoria and Piderit, 1994; Daily et al., 1999; Carter et al., 2003). In the past decade, women have increased their representation on corporate boards of directors, but critics argue that overall 
representation remains low when considering the overall percentage of women in the workforce. Using a panel of approximately 300 unregulated Fortune 1000 firms from 1990 to 1999, we document an increase in the percentage of board seats held by women of the average firm from $5.6 \%$ in 1990 to $12.26 \%$ in 1999. In addition, in $1999,87 \%$ of corporate boards had at least one woman member compared with $53 \%$ in 1990 . We find evidence of this increasing representation of women on boards despite a trend in the sample of decreasing board size.

The primary goal of this paper is to systematically assess the extent to which gender impacts the selection of a director to serve on the board. We analyze the factors affecting the likelihood of boards adding new directors, either female or male in a given year. An addition to the board may follow the departure of a male or female director, or it may simply represent an increase in board size. Following Hermalin and Weisbach's (1988) approach to analyzing additions to boards, we specify a Poisson model to analyze the likelihood of women being added to the board. We consider both supply side and demand side determinants associated with the likelihood of women being added to corporate boards. We argue that if diversity is a goal of the firm, then we are more likely to observe an addition of a woman to the board if the number of women on the board is low, even if a director is not being replaced. A diversity goal also predicts that if a female director leaves the board, there is a higher probability that another female is chosen as her replacement. We find evidence consistent with both predictions.

Our results strongly indicate that board selection is not gender neutral and that the greater number of women directors is not solely a result of an increased supply of qualified female candidates. The results suggest that although boards may have internal tastes for diversity they also appear to respond to outside pressure to add women directors. Despite finding a positive relation between return on assets and the likelihood of adding a woman to the board, event study results fail to detect any significant market reaction to female additions. Therefore, although better performing firms tend to have more women on the board, we cannot conclude that more gender diverse boards generate better firm performance.

In general, our results tend to suggest that adding women to the board does not result in value creation (or destruction). Instead, due to internal preferences or external pressure for greater board diversity, the demand for female representation allows women to self-select better performing firms. Our evidence is also consistent with firms operating in a manner consistent with tokenism. Women are added to boards when a board has low or no female representation. Efforts are made again to attract female candidates when a previous female board member leaves. We do not attempt to address the social implications of firm behavior but merely document the evidence associated with the determinants associated with director selection.

The remainder of our paper is organized in the following manner. In the next section, we review the relevant literature relating to the supply and demand side determinants associated with the gender composition of the board. Section 3 describes the sample selection process and provides descriptive statistics including an analysis of the composition of the board. Section 4 provides a description of the empirical model that analyzes the likelihood of adding a male or female to the board and the related shareholder wealth response to the addition. Section 5 concludes the paper. 


\section{Related literature}

We begin this section with a discussion of the supply and demand side determinants associated with women serving on boards and the associated literature. ${ }^{1}$ Since more women have moved into managerial positions during the last decade and the pool of qualified candidates for the board has become larger, this alone could account for their increasing, but still limited, representation in the boardroom. For example, the percentage of females in the highest paid corporate positions of the sample firms in the ExecuComp database rose from 1.6 in 1992 to 4.7 in 1999. Simply put, the increased representation of females on corporate boards may be a supply effect. However, firms may still be faced with an availability constraint since boards tend to draw from the very top of the professional hierarchy causing qualified women candidates for directorships to currently remain scarce commodities. Anecdotal evidence provides some support. Based on a recent Wall Street Journal (Lublin, 2001, B1) article that used proxy statements of the 1000 largest US companies filed in 2000, 3 of the 10 directors holding the most multiple directorships were women. ${ }^{2}$ Ann McLaughlin, of Aspen Institute, alone served on nine corporate boards, more than any other director in the sample. This overrepresentation of female directors with multiple directorships is indicative of a limited number of qualified candidates.

Alternative to supply side determinants, the increased representation of females on corporate boards may be demand-driven. Possible although not mutually exclusive explanations for the role of gender in the board selection process are: diverse boards increase firm value, firms respond to external pressure for board diversity, or firms have developed internal preferences for diversity. All would account for a greater demand for female board members.

Some recent cross-sectional studies suggest a positive relation between board diversity and firm value. Carter et al. (2003) and Adams and Ferreira (2003) find a positive relation between the percentage of women on the board of directors and firm value as measured by Tobin's q. Erhardt et al. (2003) find evidence of a positive relation between percentage of women and minorities on boards of directors and return on assets and return on investment. If women add a new perspective that is value enhancing, women will become more prevalent on boards and will be associated with more enhanced shareholder value. Alternative explanations are that better performing firms are able to focus more on diversity goals. Or if women are scarce commodities, they may have the opportunity to choose to serve on better performing firms. All of these explanations imply a positive relation between performance and number of women on the board.

Although not focusing on the composition of corporate boards, Ellis and Keys (2003) find evidence that the market values diversity of the workforce. They find that firms that appear on Fortune's list of top diversity promoting firms from 1998 to 2002 experience positive, significant abnormal returns on the announcement

1. We focus on gender representation on boards. Some previous research (e.g., Kesner, 1988; Bilimoria and Piderit, 1994) analyzes board committee structure and includes gender in the analysis. For an international perspective and additional discussions relating to gender diversity on boards see a compilation of articles in Burke and Mattis (2000).

2. Additionally, $40 \%$ were minorities. 
date. Similarly, a recent report by Catalyst (2004) analyzes corporate performance and gender diversity in top management teams. The study analyzes 353 Fortune 500 companies from 1996 to 2000 . The report documents that the 88 companies with the highest representation of women on their top management teams experienced significantly higher returns on equity and total return to shareholders when compared to the 89 companies with the lowest women's representation. These results appear fairly robust to the study's industry controls. However, the study cautions that it is exploring a link between gender diversity on top management teams and companies' financial performance and not demonstrating causation.

Contrary to their own expectations, Shrader et al. (1997) find some evidence of a significant negative relation between the percentage of female board members and certain accounting measures of performance for a sample of approximately 200 Fortune 500 companies in 1993. Shrader et al. argue that it may be necessary for a firm to achieve a critical number of female board members before they can exert positive influence, whereas in their sample few firms had more than one female board member. Their explanation, however, does not account for the negative finding.

Rather than gender diversity being directly performance related, an increase in demand for female board members may be a response to internal preferences and/or external pressure for greater diversity, suggesting that women are added to boards to achieve a desired gender mix. External pressure may arise from various sources including shareholder activism. Previous research documents increased shareholder activism in corporate governance issues in the early 1990s (e.g., Gillan and Starks, 2000; Carleton et al., 1998). Institutional investors, such as TIAACREF have been particularly vocal in demanding greater representation of both women and minorities on boards. Carleton et al. (1998) analyze the correspondence between TIAA-CREF and targeted firms concerning governance issues including board diversity. They find that 17 of the 18 firms TIAA-CREF targeted from 1993 to 1996 for board diversity placed new women or minorities on their board by June 1997. They also document statistically significant negative abnormal returns surrounding board diversity targeting by TIAA-CREF. These results suggest that firms have an incentive to avoid being targeted by TIAA-CREF or other shareholder activist groups by achieving some level of diversity on the board.

Greater demand for diversity may be based on a firm having a higher public profile than others. Agrawal and Knoeber (2001) investigate whether "a governmental taste for diversity" leads firms with greater government interaction to have more women directors. They find that factors such as greater sales to the government, greater exports, environmental regulation and lobbying were not significant in explaining the number of women on the board, leading the authors to conclude that women directors do not play a political role.

Whether corporations perceive external pressure or simply have internal preferences for diversity, some corporations explicitly identify diversity as a corporate goal. For example, in the 1998 McDonalds' proxy statement, management writes: "Diversity is an important criteria when evaluating candidates for the Board" (p. 4). Similarly, some companies set numerical targets for their workforce. ${ }^{3}$ Motorola, for example, forecast the future demographics for work- 
ers in specific disciplines such as engineering and computer science. Based on the demographics, they set goals for their management "to mirror the share of men, women, blacks, Asians, and other groups in these lines of work by 2000" (p. 66). Firms such as Hoechst Celanese and J.C. Penney also have well-defined targets for management positions based on gender and minority status. Therefore, the representation of women on boards may be based on a targeted number. Since targets regarding diversity incorporate gender as only one component of diversity, once women have representation, efforts may be made to focus on other diversity issues. Or more starkly, once the target is met, demand for additional women may evaporate.

Some empirical evidence suggests industry is significant in explaining the representation of women on corporate boards (e.g., Fryxell and Lerner, 1989; Harrigan, 1981). ${ }^{4}$ Harrigan (1981), for example, finds that women directors are more prevalent in service-oriented, labor-intensive or women's products industries than in manufacturing and diversified industries. These industries may have a greater pool of woman executives from which to obtain director candidates or have more women willing to serve on their corporate boards.

The representation of women on corporate boards has also been shown to be associated with firm specific characteristics. Carter et al. (2003), Adams and Ferreira (2003), and Agrawal and Knoeber (2001), among others, document a positive relation between firm size and the representation of women directors on boards. Adams and Ferreira (2003) argue that larger companies have greater demands for diversity since they are more in the public eye or that women are attracted to the boards of larger companies and thereby more easily recruited. Agrawal and Knoeber (2001), Carter et al. (2003), and others document a positive relation between board size and the representation of women directors on the board. Adams and Ferreira (2003) find a strong negative relation between variability in stock returns and the proportion of women on the board. They argue that when uncertainty is high, group homogeneity is more valuable.

In the following sections we build upon the existing literature to develop our empirical model to analyze both supply and demand side determinants of the gender composition of the board. First, we begin with a discussion of the sample and the associated descriptive statistics.

\section{Sample selection and descriptive statistics}

\subsection{Sample construction}

Our sample begins with the set of firms on the Fortune 500 and Service 500 lists in 1990, and we track these firms over the entire decade. ${ }^{5}$ We choose the Fortune lists for two reasons. First, Catalyst, a non-profit research and advisory or-

4. Similarly, Bertrand and Hallock (2000) document that female executives are not uniformly representing in all industrial sectors. They find that women are more likely to be managing companies that specialize in health and social services and in trade. Few women hold executive positions in agriculture, construction, mining and in heavy manufacturing industries.

5. In 1990, Fortune had two separate lists, the Fortune 500 tracked the largest U.S. industrial corporations and the Service 500 tracked the largest U.S. non-industrial corporations. 
ganization, tracks women directors in the largest Fortune 500 firms (both service and industrial), which provides an alternative source to verify our sample of women directors. ${ }^{6}$ Second, some empirical evidence suggests that the representation of women on boards of directors is greater in larger firms (e.g., Harrigan, 1981; Agrawal and Knoeber, 2001; Carter et al., 2003). In part, this is because a positive relation exists between board size and firm size. Larger boards have more seats available, potentially allowing for greater representation by women.

Consistent with Hermalin and Weisbach (1988), we restrict our analysis primarily to nonregulated industries since boards of directors for regulatory firms may be systematically different from boards of directors of non-regulatory firms (e.g., Baysinger and Zardkoohi, 1986; Subhramanyam et al., 1997). Therefore, we eliminate all financial institutions, insurance companies, and real estate firms defined as SIC codes 6000-6799. We also eliminate all electric, gas, and sanitary services (utilities) defined within the 4900 SIC codes.

To provide a sufficient time series to analyze changes in board composition, we require a complete set of proxy statements for firms for a minimum of 7 years. This restriction imposes a survivorship bias on the sample but is necessary to capture variation in the dependent variable for our analysis. Our final sample initially consists of 309 nonregulated firms for the first 7 of the 10 sample years. ${ }^{7}$ After 1996 our sample size decreases to 300, 291, and 266 firms in 1997, 1998, and 1999 , respectively, due to sources of attrition such as mergers and acquisitions.

For each sample firm, we examine proxy statements to determine board composition for each of the sample years from 1990 to $1999 .{ }^{8}$ We identify each board member as an insider or outsider. We define an insider as a current employee of the company or subsidiary, a non-officer chairman of the board or a non-officer chairman of the executive committee and all others as outsiders. ${ }^{9}$ Our definition of outsider does not distinguish between affiliated and independent outside directors since most women serve as independent outside directors. ${ }^{10}$ In addition, we determine the gender of the director, gender composition of the board, and board size for each year. We then compare the composition of the board across years to identify director turnover by gender.

\subsection{Analysis of the composition of the board in the 1990s}

We begin our analysis by describing the percentage of women on corporate boards during the 1990's. As presented in Table 1, the percentage of firms with

6. We are not able to verify with Catalyst in all years in our sample. The Catalyst Census was begun in 1993. That year woman directors were listed for firms in both the Fortune 500 and Service 500. From 1995 to 1998, only women in the top 500 firms (industrial or service) were listed, effectively cutting the Catalyst sample in half. In 1999, Catalyst sampled the Fortune 1000, which includes both industrial and service firms.

7. Our actual sample sizes vary slightly from 309, due to incomplete data availability - causing our sample size to be 302 in 1990 and 1991, 303 in 1992, 304 from 1993 to 1995, and 305 in 1996.

8. We also analyze 1989 proxies to determine changes in board composition in 1990.

9. Agrawal and Knoeber (2001), Farrell and Whidbee (2000), Klein (1998), and Hermalin and Weisbach (1991) define inside directors as corporate officers.

10. Typically, affiliated outside directors are defined as retired officers of the firm, related to a top officer of the firm or have extensive business dealings with the firm (e.g., Farrell and Whidbee, 2000). 
Table 1. Breakdown of number or percentage of women on the board in each of the sample years

\begin{tabular}{|c|c|c|c|c|c|c|c|}
\hline \multirow[b]{2}{*}{ Year } & \multirow[b]{2}{*}{$\mathrm{N}$} & \multirow{2}{*}{$\begin{array}{l}\text { Average } \\
\text { number of } \\
\text { women on } \\
\text { the board }\end{array}$} & \multirow{2}{*}{$\begin{array}{l}\text { Percent } \\
\text { women on } \\
\text { the board }\end{array}$} & \multicolumn{4}{|c|}{ Percentage of firms with: } \\
\hline & & & & $\begin{array}{c}0 \text { women } \\
\text { on the board }\end{array}$ & $\begin{array}{l}1 \text { woman } \\
\text { on the board }\end{array}$ & $\begin{array}{l}2 \text { women } \\
\text { on the board }\end{array}$ & $\begin{array}{l}>2 \text { women } \\
\text { on the board }\end{array}$ \\
\hline 1990 & 302 & 0.74 & 5.60 & 47.02 & 36.42 & 13.58 & 2.98 \\
\hline 1991 & 302 & 0.76 & 5.83 & 44.37 & 38.07 & 15.23 & 2.32 \\
\hline 1992 & 303 & 0.80 & 6.31 & 39.60 & 43.23 & 14.52 & 2.64 \\
\hline 1993 & 304 & 0.89 & 7.18 & 35.86 & 43.09 & 17.76 & 3.29 \\
\hline 1994 & 304 & 0.99 & 8.20 & 27.63 & 49.01 & 20.07 & 3.29 \\
\hline 1995 & 304 & 1.11 & 9.22 & 22.03 & 49.01 & 25.66 & 3.29 \\
\hline 1996 & 305 & 1.18 & 9.96 & 18.36 & 49.51 & 28.85 & 3.29 \\
\hline 1997 & 300 & 1.23 & 10.60 & 15.33 & 50.67 & 30.67 & 3.33 \\
\hline 1998 & 288 & 1.30 & 11.16 & 14.93 & 47.56 & 32.63 & 4.86 \\
\hline 1999 & 262 & 1.39 & 12.26 & 12.60 & 45.80 & 33.58 & 8.01 \\
\hline
\end{tabular}

Based on a sample of non-regulated Fortune 1000 sized firms that have proxy statement data available for a minimum of the first 7 years of the sample period. Sample size $(N)$ varies by year due to other missing data.

no women on the board in 1990 is $47 \%$. However, by 1999, the percentage of firms with no women on the board fell to $12.6 \%$. The table shows the percentage of firms that have one, two, or more than two women sitting on individual boards. In 1990, 36.4\% of the firms had one woman on the board, $13.6 \%$ had two women, and approximately $3 \%$ had more than two women. By 1999, the percentages increased across all three categories to $45.8 \%, 33.6 \%$, and $8 \%$, respectively. Our sample appears comparable to statistics reported in the 1999 Catalyst survey (Catalyst Census of Women Board Directors of the Fortune 1000 as of March 3 1, 1999, p. 2). Analyzing the Fortune 500 firms from 1994 to 1999, Catalyst documents a slight decline in the percentage of firms with one woman director from $46 \%$ to $45 \%$. However, the number of companies with multiple women directors increased from $29 \%$ to $39 \%$ over the comparable period.

Tables 1 and 2 show the average number of women on boards increased from 0.74 in 1990 to 1.39 in 1999. Our results are similar to Agrawal and Knoeber (2001) who document the average number of women directors in utilities and manufacturing firms rose from approximately 0.9 in 1988 to 1.5 in 1999 . Despite a decrease in board size through the 1990s as illustrated in Table 2, the representation of women has increased..$^{11}$ In addition, board composition has shifted to a greater percentage representation of outsiders sitting on the boards as evidenced by an increase in the average number of outsiders sitting on the board from 8.8 in 1990 to 9.0 in 1999 and a corresponding decrease in the number of insiders from 3.3 to 2.2 in 1990 and 1999, respectively. Table 2 shows that women overwhelmingly serve on boards as outsiders even in later sample years.

11. The decrease in board size is consistent with the trend documented by Huson, Parrino and Starks (2001) over their sample period of 1971 to 1994. 
Table 2. Breakdown of board characteristics including board size, gender and inside versus outside directors

\begin{tabular}{|c|c|c|c|c|c|c|c|c|}
\hline Year & $\mathrm{N}$ & $\begin{array}{l}\text { Average } \\
\text { Board size }\end{array}$ & $\begin{array}{l}\text { Average } \\
\text { number of } \\
\text { insiders }\end{array}$ & $\begin{array}{l}\text { Average } \\
\text { number of } \\
\text { outsiders }\end{array}$ & $\begin{array}{l}\text { Average } \\
\text { number } \\
\text { of male } \\
\text { insiders }\end{array}$ & $\begin{array}{l}\text { Average } \\
\text { number } \\
\text { of male } \\
\text { outsiders }\end{array}$ & $\begin{array}{l}\text { Average } \\
\text { number } \\
\text { of female } \\
\text { insiders }\end{array}$ & $\begin{array}{l}\text { Average } \\
\text { number } \\
\text { of female } \\
\text { outsiders }\end{array}$ \\
\hline 1990 & 302 & 12.13 & 3.34 & 8.79 & 3.31 & 8.08 & 0.03 & 0.71 \\
\hline 1991 & 302 & 12.08 & 3.25 & 8.82 & 3.25 & 8.09 & 0.03 & 0.73 \\
\hline 1992 & 303 & 12.07 & 3.14 & 8.92 & 3.15 & 8.15 & 0.03 & 0.77 \\
\hline 1993 & 304 & 11.84 & 2.93 & 8.90 & 2.90 & 8.04 & 0.03 & 0.86 \\
\hline 1994 & 304 & 11.69 & 2.74 & 8.96 & 2.71 & 7.99 & 0.03 & 0.96 \\
\hline 1995 & 304 & 11.66 & 2.63 & 9.04 & 2.59 & 7.96 & 0.03 & 1.08 \\
\hline 1996 & 305 & 11.56 & 2.51 & 9.05 & 2.48 & 7.90 & 0.03 & 1.15 \\
\hline 1997 & 300 & 11.42 & 2.45 & 8.97 & 2.42 & 7.77 & 0.02 & 1.20 \\
\hline 1998 & 288 & 11.42 & 2.35 & 9.07 & 2.32 & 7.81 & 0.03 & 1.27 \\
\hline 1999 & 262 & 11.26 & 2.23 & 9.03 & 2.20 & 7.67 & 0.03 & 1.36 \\
\hline
\end{tabular}

$\overline{\text { Based on a sample of non-regulated Fortune } 1000 \text { sized firms that have proxy statement data available }}$ for a minimum of the first 7 years of the sample period. Sample size $(N)$ varies by year due to other missing data. Insiders represent all officers of the firm (male or female), non-officer chairmen of the board and non-officer chairmen of the executive committee. All other directors are outsiders.

Table 3 provides sample statistics for the entire 10-year sample period and includes all of the variables used in subsequent specifications. The average firm has 1.03 women on the board and women represent $8.6 \%$ of the board. This compares to Adams and Ferreira (2003) who document 7.8\% women on the board with an average board size of 9.9 for a sample of 1462 firms in 1998. Carter et al. (2003) document $9.6 \%$ women on the board with an average board size of 11 for a sample of 797 Fortune 1000 firms in 1997. As a sample maximum, one firm (Avon) had six female directors and an equal percentage of men and women serving on the board. The average firm had 8.79 billion in sales, a board size of 11.72 members and a return on assets of $5.67 \%$. The average board of director compensation was US\$ 53,736, which includes annual retainer, meeting fees, stock option values and stock grants. ${ }^{12}$ On average, institutions owned approximately $57 \%$ of the stock of our sample firms.

\section{Analysis of additions to the board of directors}

For a director (female or male) to be added to a board there must be an offer by the firm and an acceptance by the nominee. Although we are primarily interested in the determinants associated with the offer decision, we are only able to observe actual hires. In effect then we use a reduced form model to regress number of Female Directors Added to a corporate board on both demand and supply determinants. For comparative purposes we also estimate a model with number of Male Outsiders Added as the dependent variable. 
Table 3. Descriptive statistics for approximately 300 non-regulated fortune 1000 sized firms that have proxy statement data available for a minimum of the first 7 years of the sample period

\begin{tabular}{lcccc}
\hline Variable & Mean & SD & Min & Max \\
\hline Number of Female Directors Added & 0.120 & 0.342 & 0 & 3 \\
Number of Male Outsiders Added & 0.589 & 0.804 & 0 & 5 \\
Females on Board & 1.03 & 0.837 & 0 & 6 \\
Proportion Females on Board (0-1.0) & 0.0857 & 0.0683 & 0 & 0.500 \\
Female Departures & 0.0514 & 0.228 & 0 & 2 \\
Male Outsider Departures & 0.677 & 0.904 & 0 & 7 \\
Insider Departures & 0.270 & 0.573 & 0 & 6 \\
Sales (US\$ millions) & 8,790 & 17,068 & 350.6 & 173,215 \\
Board Size & 11.72 & 2.73 & 4 & 33 \\
Proportion Institutional Ownership (0-1.0) & 0.572 & 0.150 & 0.067 & 0.987 \\
Compensation (US\$) & 53,736 & 40,269 & 0 & 580,253 \\
Return on Assets (0-1.0) & 0.0567 & 0.0634 & -0.494 & 0.575 \\
Standard Deviation Return & 0.0831 & 0.0269 & 0.0334 & 0.301 \\
Working Woman Ranking (binary) & 0.0746 & 0.263 & 0 & 1 \\
Females on the Board in 1989 & 0.693 & 0.797 & 0 & 4 \\
\hline
\end{tabular}

The means are for the non-lagged values of the variables even if lagged variables are utilized in the regression specification.

Percent Females on the Board is the number of women on the board divided by board size in a given year.

Female Departures equals the number of women on the board in the preceding year who left the board.

Male Outsider Departures and Insider Departures are defined analogously. Insiders represent all officers of the firm (male or female), non-officer chairmen of the board and non-officer chairmen of the executive committee.

All other directors are outsiders.

Board Size equals the number of total board members in a given year.

Compensation is real annualized director compensation defined as the sum of the annual retainer, the meeting fee times number of meetings, the end of year value of shares granted, and options granted valued at $25 \%$ of their exercise price (base year is 1995).

Working Woman Ranking equals 1 if the firm appears in the top 100 firms for working mothers ranking by Working Mother magazine; 0 otherwise.

Percent Institutional Ownership is percent of outstanding common shares owned by institutional investors.

Females on the Board in 1989 equals the number of women who sat on the firm's board in 1989.

Sales equals real firm sales revenue in millions (base year is 1995).

Return on Assets is net income divided by total assets.

Standard Deviation Return is the standard deviation of monthly stock returns from Compustat for the 5 years prior to the addition to the board.

An alternative specification for examining the factors that influence female representation on corporate boards would be to specify the dependent variable as either the number of females on the board or the percent of females on the 
board as done in previous studies (e.g., Adams and Ferreira, 2003; Carter et al., 2003; Shrader et al., 1997). ${ }^{13}$ Given the long tenure that many directors often enjoy, board composition at any point in time can be shaped by conditions accumulating over a decade or more. Therefore, a limitation to analyzing the number of women on the board is that the specification does not allow us to account for inertia in the system due to the longevity of director tenure. Further, Lehn et al. (2003) find evidence that the size and structure of boards have evolved endogenously over time. Consequently, examining changes in board composition over time better captures the issues we are attempting to address.

As noted in Table 3, the dependent variable, Number of Female Directors Added, varies from zero to three with a mean of 0.12 and a standard deviation of 0.34 . To account for the discrete nature of the dependent variable, we employ a Poisson regression model. However, the dependent variable is primarily binary. Number of Females Directors Added equals one in $95.4 \%$ of the cases where a woman joins the board in our sample. We have 14 cases where the dependent variable equals two, when two women were added to a board in a given year and only one case where the dependent variable equals three. In contrast, the companion dependent variable, Number of Male Outsiders Added, has much greater instances of multiple additions, ranging from zero to five with a mean of 0.59 and standard deviation of 0.80 . In nearly $22 \%$ of the cases where a male outsider was added, multiple male outsiders were added. Although a Probit model could be justified for female directors, a Poisson model is much more appropriate for male directors. Since the purpose of the male equation is for comparison with the female equation we estimate a Poisson model for both. ${ }^{14}$

\subsection{Defining independent variables}

If board diversity is a goal of the firm, the likelihood of a woman being added to a board should be higher, the lower the existing representation by women. To test this assertion, we include the percentage of the board that was female in the previous year (Percent Females on Board) as an explanatory variable. ${ }^{15}$ A negative coefficient suggests demand side determinants of board additions are at play. Firms add sufficient women to meet internal goals or alleviate external pressures, and once the target is met demand for additional women dissipates. This does not preclude gender being just one component of diversity and after women have representation, efforts are made to focus on other diversity issues. There are at least two possible reasons why Percent Females on Boards could have a positive effect. Existing female board members may have influence in attracting additional women to serve on the board either by iden-

13. For completeness, we also specify a model where the dependent variable is number of females on the board. The results for this specification are discussed in footnote 25.

14. We obtain very similar results using a probit specification for women. These results are available from the authors.

15. Alternatively, we could use the actual number of women on the board. Both measures of female board representation yield the same basic results. We chose the percent variable, however, because it allows for a cleaner interpretation of one of the other explanatory variables - board size. 
tifying peers for nomination or in applying internal pressure. Moreover, on the supply side, female nominees may be more attracted to firms that have already achieved some degree of board diversity.

A new addition to the board (male or female) is more likely when a vacancy occurs. The diversity motive for adding women directors strongly suggests that the likelihood of adding a female will be greater when a woman departs the board than when a man leaves. Because inside and outside directors serve different roles, the effects of a vacancy created by an insider leaving should be different than when an outsider leaves. To deal with these factors we create three variables that capture the type and/or gender of departing directors: Female Departures, Male Outsider Departures, and Insider Departures. All three variables measure the number of directors leaving the board of the specified type, in a given year. Female Departures combines both inside and outside women directors because there were too few female inside directors in our sample departing to warrant separate variables. Specifically, there were only four female insiders who departed, as compared to 151 cases of departing female outsiders. For like reasoning, Insider Departures combines men and women.

Drawing on previous research that documents relations between the representation of women on corporate boards and specific firm characteristics, we identify various firm characteristics as independent variables in our model. We include measures of firm size, board size, institutional shareholdings, board compensation, firm performance, firm risk, a proxy for cultural aspects of the firm, and industry controls in the regression specification. As previously noted, some empirical evidence suggests industry is significant in explaining the representation of women on corporate boards (e.g., Fryxell and Lerner, 1989; Harrigan, 1981). We account for these differences by combining firms into industry classifications primarily based on three- and four-digit primary SIC codes and creating industry fixed effects based on these classifications.

To capture firm heterogeneity within industries we include a number of firm specific variables, beginning with firm and board size. Firm size is measured by sales revenue as obtained from Compustat deflated by the CPI. We use log of sales in our regression analysis to minimize the effects of extreme values. We expect larger firms to be more likely to add female directors. The effect of a larger board itself is less clear. When board size is increased to make room for a woman director to meet diversity targets the power of any individual board member is diluted. At the margin, this dilution is smaller the larger the size of the existing board. Alternatively, larger boards may be less likely to add anyone, male or female, since the trend has been to reduce board size as depicted in Table 2 and noted by Huson et al. (2001). To eliminate obvious causality problems, board size is lagged 1 year.

We include the percent of institutional investor shareholdings within a firm as an explanatory variable to control for increased shareholder activism in corporate governance issues in the early 1990s (e.g., Gillan and Starks, 2000; Carleton et al., 1998). If institutional investors demand more diversity, greater institutional ownership is likely to be associated with an increased likelihood of observing a female addition to the board. But even if gender neutral, institutional investor demand for greater board independence could also lead indirectly to more women directors, as women are more likely to fulfill an outside director role. 
Board compensation may play a role in the gender composition of the board. It is standard practice for all of a firm's directors to be paid equal annual retainers, board meeting fees, stock options and stock grants. The primary variation in director compensation within a firm is due to fees associated with different committee assignments. If women directors are in high demand, relative to men, they should be able to command a premium in the marketplace. Since all directors at a company receive the same basic compensation, this premium can only manifest itself if women have the option of selecting to serve on higher paying boards. Specifically, if demand drives the representation of women on boards, we would expect a positive relation between the number of women directors serving on a board and board compensation. If women are not in relatively high demand, compensation should be gender neutral.

We measure director compensation using data in ExecuComp regarding annual retainer, meeting fees, number of meetings, additional shares of stock granted, and stock options granted. For years prior to 1992 or missing data in ExecuComp, we obtain the data from proxy statements. We estimated the annual director compensation to be the sum of the previous year's annual retainer, the meeting fee times number of meetings, the end of year value of shares granted to directors, and a measure of options value. Since our data does not allow us to compute option values using the Black-Scholes model, we follow Core et al. (1999) who valued CEO options at $25 \%$ of their exercise price. This procedure was adopted by Brick et al. (2002) to measure directors' option values. Because this is a crude proxy we also use different measures of option value $(0 \%, 50 \%, 75 \%$, and $100 \%$ of exercise price) as robustness checks. Compensation is deflated by the CPI and entered in log form. We use previous year director compensation since it would be what the director candidate would use as the basis to determine expected compensation.

In addition to focusing on the diversity goal, we draw on previous research that analyzes the determinants associated with the individual director selection process. Hermalin and Weisbach (1988) find that independent outside directors are more likely to join and inside directors are more likely to leave a board after the firm has experienced poor performance. They argue that poor performance influences the selection process since non-CEO inside directors may be blamed for poor performance, and, to the extent that the poor performance indicates a need for additional monitoring, an outside director replacement becomes more likely. In the context of our study, this previous evidence suggests that the likelihood of adding an outside director is greater when a firm experiences poor performance, but it does not make a prediction with regard to gender differences. Extending Hermalin and Weisbach's argument would suggest that an addition of a male or female director is greater when the firm experiences poor performance. Therefore, we include a measure of firm performance using lagged return on assets (ROA) calculated as net income divided by total assets.

Even if diversity on the board is a value-enhancing strategy, it is not obvious that adding a woman to the board will be associated with previous performance. For example, if a firm already has a well-diversified board and is performing well, the decision associated with a new director may be gender neutral. In addition, women may self-select to serve on better performing firms. Therefore, from a value enhancing perspective, we make no prediction regarding firm performance and the probability of adding a woman to the board. 
Since previous research (Adams and Ferreira, 2003) finds a negative relation between variability in stock returns and the proportion of women on the board, we include a firm risk variable measured as the standard deviation of monthly stock returns from Compustat for the previous 5-year period. Again, women may self-select to serve on boards of lower risk firms. ${ }^{16}$ We expect a negative relation between the variability in stock returns and the likelihood of adding a woman to the board.

To account further for firm level heterogeneity, particularly the cultural aspects of the firm that pertain to women, we obtained rankings from Working Mother magazine that rates the top "100 Best Companies for Working Mothers". The magazine ranks firms based on five categories; childcare, flexibility, leave for new mothers, work/life benefits and advancement of women. We obtained the rankings for 1989 to 1999 and created a dummy variable equaling one if a firm appeared in the rankings of the prior year and zero otherwise. ${ }^{17}$ The variable, Working Woman Ranking, attempts to measure a culture in the firm that values family friendly policies. Our expectation is that these firms are more likely to add women to the board because of a greater demand for women directors and a comparative advantage in their recruitment. Therefore, we expect a positive relation between the Working Woman Ranking variable and the likelihood of adding a women to the board. The Working Mother ranking as a measure of firm culture has several drawbacks. First, a failure to be ranked in the Top 100 does not imply that the firm is not family friendly. ${ }^{18}$ Firms are chosen by Working Mothers magazine from a sample of applications voluntarily submitted by corporations. Second, the ranking may not fully correlate with the value a firm places on woman directors or what attracts them to a particular firm.

To account for unobservable cultural affects at the firm level, we assume firms that had women on the board in the late 1980s have, ceteris paribus, a higher demand for (or are more attractive to) women directors than other firms. We expect that female representation in the late 1980s increases the probability of adding additional women to the board in a given year in the 1990s. We measure female representation in the late 1980s by the number of female directors on a firm's board in 1989, the year preceding the start of the sample (Females on the Board in 1989). ${ }^{19}$

Finally, to account for changes in the overall pool of potential women directors across time, we include nine dummy variables for the years 1991 to 1999, making the base year 1990. Just as the number of women on boards has increased over the decade of the 1990s, so did the pool of available candidates. Part of this is due to the increased representation of women in the work force, but particularly

16. Women directors selecting lower risk firms are consistent with evidence provided by Jianakoplos and Bernasek (1998) who find that single women exhibit more risk aversion in financial decision making than single men.

17. The ranking is published in the October issue of Working Mother of each year. Therefore, we use the October ranking for data obtained from proxies in the subsequent year.

18. See Preece and Filbeck (1999) for a more thorough discussion of the Working Mother list and the potential drawbacks to firms that appear on the list.

19. It is possible that a firm had a woman director prior to 1989 who had left the firm by 1989 and was not replaced by another woman. 
those having corporate executive experience. The year dummies further control for changes in societal attitudes regarding diversity that could increase the overall demand for women on boards of directors.

\subsection{Discussion of empirical results}

Table 4 documents the regression results for the addition of women to the board in columns 1 and 3 and the addition of men in columns 2 and 4 with and without industry fixed effects. ${ }^{20}$ When we analyze the regression specification for women (columns 1 and 3), we find that a lower percentage of women on the board in the previous period significantly increases the likelihood that a woman will be added to the board in the current year. This increase at least partially comes at the expense of additional male directors as indicated by the second column of the table, where Percent Females on the Board is positive and significant. This evidence tends to support diversity considerations as a prime reason why women were chosen to serve on boards in the 1990s. The glass-ceiling connotation is that a higher percentage of women in place eliminates the need for more.

The likelihood of a male or a female being added to the board is positively and significantly related to Female Departures and also positively related to Male Outsider Departures. Insider Departures have no impact on whether a female is added to the board but is significant and positively related to when a male outsider is added to the board. The latter result reflects the sample statistic that few insiders are women, but also indicates that male outsiders are closer substitutes for insiders than are female outside directors.

To assess more fully the effects of a male or female departure we use the coefficients in Table 4 to calculate probability changes. The probability of adding at least one female (male), based on the Poisson model, is given by 1 - (Probability of adding no females) $=1-\mathrm{e}^{-\lambda i} \lambda^{0} / 0 !=1-\mathrm{e}^{\lambda i}$, where $\lambda=\mathrm{e}^{\beta x}$ and $x$ is a vector of values for the explanatory variables and $\beta$ their regression coefficients. To create a base case of "No Departures," all the departure variables are set to zero, Board Size is assumed to be 10 with one female on the board. Consequently, Percent Females on the Board equals 0.10. All the remaining variables are evaluated their sample means. In the case of a female departing, Female Departures is set to one, the other departures variables are set to zero. Male Outsider probabilities are calculated analogously. ${ }^{21}$ We report the probabilities in Table 5.

In the baseline case of No Departures, the likelihood of adding a woman is $10.9 \%$ compared to the likelihood of adding a man, $42.9 \%$. As expected, the departure of any board member increases the probability of adding either a man or a woman

20. The inclusion of industry fixed effects requires firms to be in an industry that added at least one woman to a board over the sample period (i.e., that there be some variation in the dependent variable for each group). This restriction eliminated two firms that failed to add any women to their boards over the 10-year period and could not reasonably be combined with other firms into an industry classification. An alternative approach would be to use firm, rather than industry fixed effects in the regressions. For a large number of firms there would be no variation in the dependent variable, as they did not add a woman to their boards over the sample period. Dropping these firms from the analysis would result in sample selection bias.

21. For further elaboration on obtaining Poisson probabilities, see Greene (1993). 
Table 4. Poisson regression where the dependent variable is the number of females or male outside directors added to the board of a firm in a given year

\begin{tabular}{|c|c|c|c|c|}
\hline & Female & Male Outsider & Female & Male Outsider \\
\hline $\begin{array}{l}\text { Percent Females on the Board } \\
\quad \text { (lagged) }\end{array}$ & $-19.6^{*}(0.000)$ & $2.38^{*}(0.000)$ & $-12.7^{*}(0.000)$ & $1.26^{*}(0.0146)$ \\
\hline Female Departures & $1.46^{*}(0.000)$ & $0.175^{*}(0.0654)$ & $1.29 *(0.000)$ & $0.170^{*}(0.0701)$ \\
\hline Male Outsider Departures & $0.159 *(0.0028)$ & $0.430 *(0.000)$ & $0.184^{*}(0.0003)$ & $0.421 *(0.000)$ \\
\hline Insider Departures & $-0.0861(0.387)$ & $0.175^{*}(0.000)$ & $-0.0485(0.598)$ & $0.157^{*}(0.0001)$ \\
\hline Log Sales & $0.224 *(0.0194)$ & $0.146^{*}(0.0001)$ & $0.0777(0.208)$ & $0.0721^{*}(0.0063)$ \\
\hline Board Size (lagged) & $-0.0226(0.426)$ & $-0.114^{*}(0.000)$ & $-0.0352(0.137)$ & $-0.0757^{*}(0.000)$ \\
\hline Percent Institutional Ownership & $1.10 *(0.0327)$ & $-0.116(0.597)$ & $0.611(0.124)$ & $0.0250(0.882)$ \\
\hline Log Compensation & $0.129(0.344)$ & $0.0424(0.349)$ & $0.138(0.213)$ & $0.0565(0.151)$ \\
\hline Return on Assets (lagged) & $1.93(0.1097)$ & $-0.845^{*}(0.0563)$ & $1.15(0.173)$ & $-0.937 *(0.0193)$ \\
\hline $\begin{array}{l}\text { Standard Deviation Return } \\
\text { (lagged) }\end{array}$ & $-9.24^{*}(0.0172)$ & $1.70(0.237)$ & $-6.62^{*}(0.0107)$ & $-1.23(0.260)$ \\
\hline $\begin{array}{l}\text { Working Woman Ranking } \\
\text { (lagged) }\end{array}$ & $0.430 *(0.0570)$ & $-0.0534(0.623)$ & $0.499 *(0.0060)$ & $-0.0254(0.787)$ \\
\hline Females on the Board in 1989 & $0.706^{*}(0.000)$ & $-0.0319(0.537)$ & $0.524 *(0.000)$ & $-0.0103(0.809)$ \\
\hline Year 91 & $0.254(0.386)$ & $-0.116(0.269)$ & $0.132(0.650)$ & $-0.124(0.234)$ \\
\hline Year 92 & $0.294(0.318)$ & $-0.161(0.130)$ & $0.206(0.480)$ & $-0.159(0.131)$ \\
\hline Year 93 & $0.732^{*}(0,0069)$ & $-0.256^{*}(0.0165)$ & $0.594 *(0.0251)$ & $-0.276^{*}(0.0091)$ \\
\hline Year 94 & $0.884^{*}(0.0010)$ & $-0.267^{*}(0.0132)$ & $0.738 *(0.0048)$ & $-0.285^{*}(0.0074)$ \\
\hline Year 95 & $1.10^{*}(0.0001)$ & $-0.243^{*}(0.0233)$ & $0.851^{*}(0.0012)$ & $-0.240 *(0.0231)$ \\
\hline Year 96 & $0.990 *(0.0005)$ & $-0.383 *(0.0006)$ & $0.700 *(0.0100)$ & $-0.381^{*}(0.0005)$ \\
\hline Year 97 & $0.726^{*}(0.0188)$ & $-0.268^{*}(0.0166)$ & $0.451(0.123)$ & $-0.276^{*}(0.0114)$ \\
\hline Year 98 & $1.057^{*}(0.0004)$ & $-0.272 *(0.0185)$ & $0.701 *(0.0135)$ & $-0.259 *(0.0203)$ \\
\hline Year 99 & $1.35^{*}(0.000)$ & $-0.366^{*}(0.0020)$ & $0.928 *(0.0009)$ & $-0.323^{*}(0.0048)$ \\
\hline Industry Fixed Effects & Yes & Yes & No & No \\
\hline Log likelihood & -806.1 & -2565.5 & -1029.9 & -2853.9 \\
\hline Sample size & 2974 & 2974 & 2974 & 2974 \\
\hline
\end{tabular}

The dependent variable ranges from 0 to 3 for the female regression and from 0 to 5 for male outsider regression.

$p$-values are in parentheses.

Percent Females on the Board is the number of women on the board divided by board size in a given year.

Female Departures equals the number of women on the board in the preceding year who left the board.

Male Outsider Departures and Insider Departures are defined analogously. Insiders represent all officers of the firm (male or female), non-officer chairmen of the board and non-officer chairmen of the executive committee.

All other director are outsiders.

Board Size equals the number of total board members in a given year.

Log Compensation is the log of real annualized director compensation defined as the sum of the annual retainer, the meeting fee times number of meetings, the end of year value of shares granted, and options granted valued at $25 \%$ of their exercise price (base year is 1995).

Log Sales equals log of real firm sales revenue in millions (base year is 1995).

Working Woman Ranking equals 1 if the firm appears in the top 100 firms for working mothers ranking by Working Mother magazine; 0 otherwise.

Percent Institutional Ownership is percent of outstanding common shares owned by institutional investors.

Females on the Board in 1989 equals the number of women who sat on the firm's board in 1989.

Return on Assets is net income divided by total assets.

Standard Deviation Return is the standard deviation of monthly stock returns from Compustat for the 5 years prior to the addition to the board.

Year $9 i$ is a year dummy ( $i=1$ to 9 ).

Industry Fixed Effects are for 103 industries.

* Significant at conventional levels. 
Table 5. Calculated probabilities based on Table 4 coefficients of adding a female or male to the board of directors assuming no departures, a female departure or a male departure from the board of directors

\begin{tabular}{lll}
\hline & $\begin{array}{l}\text { Probability of adding at least } \\
\text { one new female director }\end{array}$ & $\begin{array}{l}\text { Probability of adding at least } \\
\text { one new male outsider director }\end{array}$ \\
\hline No departures & 0.109 & 0.429 \\
If a female departed & 0.393 & 0.488 \\
If a male outsider departed & 0.127 & 0.578 \\
\hline
\end{tabular}

Using the coefficients in Table 4 , this table shows the probability of adding at least one female (male), based on the Poisson model, and is given by given by 1 - (Probability of adding no females) = $1-\mathrm{e}^{-\lambda i} \lambda \lambda^{0} / 0 !=1-\mathrm{e}^{\lambda i}$, where $\lambda=\mathrm{e}^{\beta x}$ and $x$ is a vector of values for the explanatory variables and $\beta$ their regression coefficients. To create a base case of "No Departures," all the departure variables are set to zero, Board size is assumed to be 10 with one female on the board. Consequently Percent Females on the Board equals 0.10. In the case of a female (male) departing, Female Departures (Male Outsider Departures) is set to one, the other departures variables are set to zero.

to the board. However, if a woman leaves the board, the likelihood of adding a woman jumps to $39.3 \%$ from $10.9 \%$. If a male outsider leaves, the probability of adding a woman is $12.7 \%$, only slightly higher than if no departures from the board had occurred at all. In contrast, the probability of adding a male outsider rises from $42.9 \%$ to $57.8 \%$ when a male outsider departs the board and rises to $48.8 \%$ when a woman departs. These probabilities support the interpretation that the demand for directors is gender related, with firms attempting to maintain diversity.

Although not reported in Table 5, we also attempt to determine the impact of the percentage of women on the board in the previous period. We recalculate the probabilities assuming the board size equals 10 (as in the previous analysis) but that the percentage of women on the board is 0.20 instead of 0.10 . Essentially, we modify the probability calculations assuming two women served on the board in the previous year. In this scenario, and assuming no board departures, the probability of adding at least one woman is only $1.61 \%$, whereas the probability of adding a male is $50.9 \%$. Essentially, if $20 \%$ of the board is female, the probability of adding another female is close to zero.

Turning to the other explanatory variables in our model, larger firms, as measured by sales, were more likely to add a man or a woman to their boards although this result appears sensitive to industry controls for women. Consistent with the descriptive statistics of decreasing board sizes over the sample period, the results suggest that larger firms were less likely to decrease (or not increase) their board size relative to smaller firms, resulting in a higher probability of adding a director of either gender. Board size itself is insignificant in the female equation, but negative and significant in the male equation. The downsizing of boards apparently came at the expense of male and not female directors.

Percent institutional ownership appears to be positively related to the likelihood of adding a female to the board although this result is sensitive to including industry effects. Institutional ownership has no explanatory power in the male regressions. To the extent that institutional ownership captures external pressure for diversity, the results are consistent with an increased demand by firms for diversity.

We find no evidence that board compensation influences the likelihood of adding a male or female director suggesting that if a greater demand exists for fe- 
male directors it does not translate into women selecting higher paying boards. This result is robust to alternative specifications of the compensation variable, including total compensation, cash compensation, incentive compensation, and various combinations of these.

Firm performance is positively related to the likelihood of adding a female (in the industry fixed effects model only) and negatively related to adding a male outsider. We find a negative relation between firm risk, measured as the standard deviation in monthly stock returns, and the likelihood of adding a female to the board. The corresponding elasticity suggests that for a $1 \%$ increase in the standard deviation of stock returns, there is a $1.27 \%$ decrease in the number women added to the board. Firm risk has no explanatory power in the male regressions. The negative relation between firm performance and adding a male outsider is consistent with Hermalin and Weisbach (1988) who find that independent outside directors are more likely to join a board after the firm has experienced poor performance. That performance has a nonnegative impact on adding a female indicates some offsetting effect. To the extent that women are in high demand, they can be more selective in the boards that they choose to serve on. Thus, we would expect to observe women choosing better performing firms and lower risk firms. In other words, if women are scarce commodities, it may be more difficult for poorly performing firms or high-risk firms to attract qualified women directors.

If a firm was ranked in the top 100 firms by Working Mothers or if at least one woman sat on the board of a firm in 1989, then we find that the firm is more likely to add a woman to the board as noted in Table 4 . To determine the economic significance of women serving on a firm's board in 1989, we again recalculate the base probabilities assuming no one leaves the board, board size is 10, the percentage of women on the board is 0.10 and number of women on the board in 1989 is 0 . The probability of adding a woman is $6.8 \%$. If women served on the board in 1989 , the associated probability of adding a woman rises to $13.3 \%$. These results suggest that some firms may continue to foster a culture that is more likely to result in additional women serving on boards.

Based on the coefficients of the year dummy variables, the likelihood of adding additional women trended upward over the decade, although the coefficients for 1991 and 1992 are statistically insignificant. Overall, these results indicate that the pool of available women candidates has increased or that the demand for diversity increased over the decade. The same trend does not appear for additions of males to the board. Instead, the likelihood of adding a male is negative and significant for all year dummy variables except 1991 and 1992.

As an alternative proxy for the pool of available women directors, we calculated the percentage of the most highly paid executives who were women as reported in ExecuComp (Percent Top Female Executives). ${ }^{22}$ The data indicate that from 1992 to 1999 the percentage of females in the highest paid corporate positions of the largest publicly held firms rose from $1.6 \%$ to $4.7 \%$. Brickley et al.

22 Proxy statements disclose compensation for the top five paid executives of the reporting company. The ExecuComp database began tracking executive compensation from the proxies in 1992. Because the ExecuComp data begin in 1992, figures for 1990 and 1991 were generated by linear extrapolation. Alternatively, we included the 1992 figure for 1990 and 1991 and our results were unaffected. 
(1994) find in their sample of firms that only $11.9 \%$ of the board is comprised of non-business executives (private investors, educators, government, and clergy) while an additional $8 \%$ of the board is comprised of retired business executives. Therefore, Percent Top Female Executives captures the largest pool of potential women directors. One problem with this variable is that it only captures potential business directors and not the pool of non-business directors (i.e., lawyers, politicians, and academicians). We would expect Percent Top Female Executives to be highly correlated with the overall supply of non-business executives. ${ }^{23}$

We expect that each year as the pool of qualified women increases, the probability of observing women added to corporate boards also increases. Because Percent Top Female Executives does not vary cross-sectionally, including it with the time dummies would result in perfect collinearity. An alternative would be to replace the time dummies with a linear time trend variable to account for non-supply related factors. This is not possible either, however, because Percent Top Female Executives is highly correlated with the linear time trend (correlation coefficient of 0.99). Therefore, we include this variable in place of the time dummies and find that it is significantly positive in the female equation and negative but insignificant in the male equation. The sign and significance of the remaining variables are unaffected. Since our results are qualitatively the same independent of our choice of proxy, the results with Percent Top Female Executives in place of the year dummies are not reported in the tables but are available from the authors upon request.

Individual industry fixed effects are not reported in the tables, but based on a likelihood ratio test they are collectively significant at the $1 \%$ level in both the female equations and male equations. This suggests that industry factors do influence the representation of women on corporate boards, consistent with previous findings by Fryxell and Lerner (1989) and Harrigan (1981).

Overall, we interpret the results from Tables 4 and 5 to suggest that diversity has been a primary determinant of the gender composition of boards in the 1990s. ${ }^{24}$ Despite documenting a positive relation between firm performance and the likelihood of adding a woman to the board, we argue that women self-select better performing firms or that better performing firms are able to focus more on diversity issues. To better address the relation between gender diversity on boards and firm performance, we analyze the market response to the announcement of an addition of a female director to the board.

23. To support this assertion, we gathered data from the AACSB membership directory and determined the percentage of accredited business programs that employed female deans over our entire sample period. We found that the percentage of female deans serving at AACSB accredited business programs increased or remained fairly constant from year to year. Overall, the correlation between Percent Top Female Executives and AACSB female deans over the 1992-1999 time period is 0.87 . Our results are insensitive to the choice of proxy.

24. We also estimate a Poisson regression model using the dependent variable Females on Board. We find that our proxies for firm size, board size, percent institutional ownership, and the working woman ranking variable are positively related to the number of women on the board. Percent inside directors serving on a board and firm risk are negatively related to the number of women on the board. We find a positive relation between firm performance and the number of female directors although our result is sensitive to the inclusion of industry fixed effects. The coefficients on the year dummy variables trend monotonically upward over the decade, although the coefficients for 1991 and 1992 are statistically insignificant. Overall, the results indicate that there are systematic differences in the number of female directors on corporate boards both across firms and across time. A full set of results for this model specification is available from the authors. 


\subsection{Event study analysis}

Previous research associated with the market response to outside director appointments find mixed results. Rosenstein and Wyatt (1990) find a significantly positive reaction to the appointment of outside directors between 1981 and 1985, but this effect is driven by the small firms in their sample. Analyzing announcements of appointments of independent outside directors between 1990 and 1994, Block (1999) finds significantly positive cumulative abnormal returns. However, the statistical significance of adding an independent outside director is largely eliminated when the percentage of independent outside directors on the board is greater than $50 \%$ or institutional ownership in the firm increases.

We searched the Lexis-Nexis Business News database for the announcement of a woman director being added to the board. We found announcement dates for 287 of our 355 additions of women to the board. We eliminated firms that announce multiple additions to the board that include a combination of male and female directors (74 multiple announcements). Our analysis is complicated by the empirical regularity that most board additions occur either at scheduled board meetings that involve other information releases or are communicated through proxy mailings and ratified by shareholders at annual meetings. We eliminated firms that announced confounding events such as mergers, acquisitions, dividend changes, stock repurchases, stock splits, and earnings, in the Wall Street Journal Index during a 5-day window around the event date (day 0). Firms must be listed in the CRSP database and have return data available during the estimation period. Our final sample consists of 111 announcements. We also identify a subsample of these firms that add a woman to an all male board (51 clean announcements out of 133 announcements of women added to all male boards).

We employ the market model event study methodology to investigate return behavior surrounding the announcement of an addition of a woman to the board and the addition of a woman to an all male board. We estimated the market model over the 150-day period preceding 20 days before the announcement date, and then we investigated return behavior over the day -1 to 0 and -1 to +1 window immediately surrounding the event date. Analyzing our results for the full sample of women additions, we find virtually no wealth impact around the announcement date of a woman being added to the board. The event window $(-1,0)$ cumulative abnormal return (CAR) is -0.00083 and the event window ($1,+1)$ CAR is 0.000966 , neither of which are significantly different from zero with $t$-statistics of -0.36 and 0.34 , respectively. In addition, $45 \%$ of the firms exhibit positive abnormal returns on the event date (day 0). Similarly, analyzing the subsample of firms that add a woman to an all male board, we find insignificant CARs around the event window $(-1,0)$ and $(-1,+1)$ of -0.000514 and -0.000981 , respectively. ${ }^{25}$ Given that most female directors in our sample are outside directors and serve on boards of large firms with a large percentage of institutional ownership, our results appear consistent with Rosenstein and Wyatt (1990) and Block (1999).

25. We performed the event study analysis on the sample of firms without eliminating confounding events and found insignificant CARs of -0.000403 and 0.000326 for the event windows $(-1,0)$ and $(-1,+1)$, respectively. For the subsample of firms, we found insignificant CARs around the event windows $(-1,0)$ and $(-1,+1)$ of -0.000508 and 0.000535 , respectively. 
To the extent that firms choose qualified candidates to serve on the board, we would not expect a market response unless the announcement conveys information that the candidate is more or less qualified than expected. Alternatively, a market response may suggest that gender diversity on the board is value enhancing for the firm. Overall, our event study results suggest that there is no wealth effect associated with the announcement of a woman being added to the board of directors of a firm even if the firm previously had an all male board. Consequently, we cannot link the increased representation of women on corporate boards to expectations of enhanced firm performance.

\section{Conclusion}

Representation by females on corporate boards in our sample steadily increased from $5.6 \%$ in 1990 to $12.26 \%$ in 1999 . In addition, $87 \%$ of the sample corporate boards had at least one woman member in 1999 compared with 53\% in 1990. Evidence presented in this paper indicates that the likelihood of women being added to specific corporate boards in a given year was negative and significantly related to the percentage of woman on those boards in the previous year. The increase in female representation on boards appears to be partially at the expense of additional male directors. In addition, a woman departing from a board significantly and materially increases the likelihood of a woman being added to the board. The results, therefore, clearly indicate that gender impacts the choice of director.

Although we find evidence that women tend to serve on better performing firms, we also document insignificant abnormal returns on the announcement date of a woman added to the board. These results are unchanged whether we analyze all cases where a woman was added to a board or a subsample of firms that add a woman to an all male board. Therefore, we fail to find convincing evidence that gender diversity in the corporate boardroom, on average, is a value enhancing strategy.

If diversity is not a value enhancing strategy, then why the demand for board diversity? One possibility is that firms may simply be responding to outside pressure to create greater diversity. Our finding of a positive relation between institutional ownership and female board additions supports this view. ${ }^{26}$ Consequently, as firms satisfied minimal expectations, they no longer actively sought greater diversity. This does not imply that women added to a board are not qualified (e.g., we do not observe a negative share price effect), just that there is a preference given to adding a female board member until the diversity goal is met. A more benign view is that firms have an internal demand for board diversity, with corporate tastes reflecting those of society at large. If firms experienced difficulty in finding qualified female candidates during the past decade, then those firms with lower female representation may have aggressively attempted to add women to their boards relative to firms that had already established greater female representation. Whether the demand for diversity is generated internally or externally or both, we conclude that gender clearly played a role in awarding corporate directorships in the 1990s.

26. This need not imply that institutions are significantly altering their portfolios in response to the lack or presence of women on a board, but rather as in the case of TIAA-CREF, asserting their influence to add women to the boards of companies in which they have holdings. 


\section{Acknowledgments}

We appreciate the helpful comments and suggestions of Sam Allgood, Richard DeFusco, Jeffry Netter (editor), Jodi Messer Pelkowski, Zekiye Selvili, and seminar participants at the University of Nebraska-Lincoln, the University of Kansas, the University of Delaware, Washington State University, and the Financial Management Association meeting in 2003. Kathleen Farrell acknowledges receiving support from the 2001 Hicks Foundation Summer Research Grant. We are responsible for all errors in the manuscript.

\section{References}

Adams, R., Ferreira, D., 2003. Diversity and incentives: evidence from corporate boards. Working Paper, University of Stockholm.

Agrawal, A., Knoeber, C., 2001. Do some outside directors play a political role? Journal of Law and Economics 44, 179-198.

Baysinger, B., Zardkoohi, A., 1986. Technology, residual claimants and corporate control. Journal of Law, Economics, and Organization 2, 339-349.

Bertrand, M., Hallock, K., 2000. The gender gap in top corporate jobs. NBER Working Paper Series.

Bilimoria, D., Piderit, S., 1994. Board committee membership: effects of sex-based bias. Academy of Management Journal 37, 1453- 1477.

Block, S., 1999. The role of nonaffiliated outside directors in monitoring the firm and the effect on shareholder wealth. Journal of Financial and Strategic Decisions 12, 1-8.

Brick, LE., Palmon, O., Wald, J. K., 2002. CEO compensation, director compensation, and firm performance: Evidence of cronyism. Working Paper, Rutgers University.

Brickley, J. A., Coles, J. L., Rory, T. L., 1994. Outside directors and the adoption of poison pills. Journal of Financial Economics 35, 371-390.

Burke, R., Mattis, M. (Eds.), 2000. Women on Corporate Boards of Directors. Kluwer Academic Publishing, Netherlands.

Carleton, W. T., Nelson, J. M., Weisbach, M. S., 1998. The influence of institutions on corporate governance through private negotiations: Evidence from TIAA-CREF. Journal of Finance 53, 1335-1362.

Carter, D. A., Simkins, B. J., Simpson, W. G., 2003. Corporate governance, board diversity, and firm value. Financial Review 38, 33-53.

Catalyst Census of Women Board Directors of the Fortune 1000 as of March 31, 1999 (Catalyst, New York).

Catalyst, 2004. The Bottom Line: Connecting Corporate Performance and Gender Diversity (Catalyst, New York).

Core, J., Holthausen, R., Larcker, D., 1999. Corporate governance, chief executive officer compensation, and firm performance. Journal of Financial Economics 51, 371-406.

Daily, C. M., Certo, S. T., Dalton, D. R., 1999. A decade of corporate women: Some progress in the boardroom, none in the executive suite. Strategic Management Journal 20, 93-99.

Ellis, K. M., Keys, P. Y., 2003. Stock returns and the promotion of workforce diversity. Working Paper, University of Delaware.

Erhardt, N. L., Werbel, J. D., Shrader, C. B., 2003. Board of director diversity and firm financial performance. Corporate Governance: An International Review 11, 102-111.

Farrell, K. A., Whidbee, D. A., 2000. The consequences of forced CEO succession for outside directors. Journal of Business 73, 597-627.

Fryxell, G. E., Lerner, L. D., 1989. Contrasting corporate profiles: Women and minority representation in top management positions. Journal of Business Ethics 8, 341 -352. 
Gillan, S. L., Starks, L. T., 2000. Corporate governance proposals and shareholder activism: The role of institutional investors. Journal of Financial Economics 57, 275-305.

Greene, W. H., 1993. Econometric Analysis. Macmillan, New York.

Harrigan, K. R., 1981. Numbers and positions of women elected to corporate boards. Academy of Management Journal 24, 619-625.

Hermalin, B. E., Weisbach, M. S., 1988. The determinants of board composition. RAND Journal of Economics 19, 589-606.

Hermalin, B. E., Weisbach, M. S., 1991. The effects of board composition and direct incentives on firm performance. Financial Management, 101-112.

Himelstein, L., 1997 (February 17). Breaking through. Business Week, 64-70.

Huson, M. R., Parrino, R., Starks, L. T., 2001. Internal monitoring mechanisms and CEO turnover: A long-term perspective. Journal of Finance 56, 2265-2297.

Jianakoplos, N. A., Bernasek, A., 1998. Are woman more risk averse? Economic Inquiry 36, 620-630.

Kesner, I. F., 1988. Directors characteristics and committee membership: An investigation of type, occupation, tenure, and gender. Academy of Management Journal 31, 66-84.

Klein, A., 1998. Firm performance and board committee structure. Journal of Law and Economics 41, 275-303.

Lehn, K., Patro, S., Zhao, M., 2003. Determinants of the size and structure of corporate boards: 1935-2000. Working Paper, University of Pittsburgh.

Lublin, J. S., 2001. Multiple seats of power: companies are cracking down on number of directorships board members can hold. Wall Street Journal (January 23), B1:B4.

Preece, D. C., Filbeck, G., 1999. Family friendly firms: does it pay to care? Financial Services Review 8, 47-60.

Rosenstein, S., Wyatt, J. G., 1990. Outside directors, board independence, and shareholder wealth. Journal of Financial Economics 26, 175-191.

Shrader, C. B., Blackburn, V. B., Iles, P., 1997. Women in management and firm financial performance: An exploratory study. Journal of Managerial Issues 9, 355-372.

Subhramanyam, V., Rangan, N., Rosenstein, S., 1997. The role of outside directors in bank acquisitions. Financial Management 26, 23-36. 